\title{
METHOXYFLURANE IN PAEDIATRIC CARDIAC SURGERY
}

\author{
S M HART, M B (NUI), F.F A I CS, \\ I A SLOAN, M B, F F A R C S, FRCP (C), \\ AND A W CONN, M D, B SC (MED), FRCP (C), F A CA *
}

INHALATION ANAESTHESIA combined with hyperventilation is a suitable technique in children, especially for operations where controlled respiration is required but muscular relaxation is unnecessary Halothane with $\mathrm{N}_{2} \mathrm{O}-\mathrm{O}_{2}$ and hyperventilation provides satısfactory maintenance anaesthesia for paediatric cardiac surgery In addition, immediate recovery is easily achieved Poor analgesia and cardiovascular depression, however, ale two disadvantages associated with the use of this agent For this reason, trichlorethylene has recently been substituted for halothane in neurosurgery using the same technique ${ }^{1}$ Results have been encouraging the blood pressure is stable throughout anaesthesia, there is excellent analgesia in the postoperative period, but recovely is prolonged if this agent is not withdiawn well before the end of surgery However, trichlorethylene is not sufficiently potent for use in cardiac surgery Alternatively, methoxyflurane has about twice the potency of halothane ${ }^{2}$ and is stated to provide considerable analgesia which persists into the postoperative period ${ }^{3-9}$ Clinical experiences with this agent in 50 children who underwent surgery for the correction of congenital heart defects are reported in this paper

\section{Method}

Of these children, 46 ranged in weight from 26 to $109 \mathrm{lb}$, and received pentobarbital $1 \mathrm{mg} / \mathrm{lb}$, pethedine $06 \mathrm{mg} / \mathrm{lb}$, and atropine $0012 \mathrm{mg} / \mathrm{lb}$ as a premedication Four children who weighed under $20 \mathrm{llb}$ seceived only atropine Thiopentone sodium 1-2 $\mathrm{mg} / \mathrm{lb}$, was used for induction in all but two cases, and suxamethonium chloride for intubation The patients weie then hypervent1lated with a high flow of nitrous oxide and oxygen using a semi-closed sysiem and Waters canistel of appropriate size Methoxyflurane was delivered from a Pentec vaporizer situated outside the curcuit When complete apnoea was required during surgery, additional suxamethonium chloride was used In those cases where cardiac bypass was performed, a Pentec vaporizer was inserted in line with the oxygen inflow to the disks $\mathbb{A}$ summary of the lesions operated upon is given in Table I

\section{Results}

The depth of anaesthesia was sufficient in all patients to allow a venous cutdown to be performed within 5 minutes following the intravenous induction

"Department of Anaesthesia, Hospital for Sick Children, Toronto 
TABLE I

Types of Paticnts

\begin{tabular}{lc}
\hline \multicolumn{1}{c}{ Lesion } & No of patients \\
\hline Patent ductus arteriosis & 13 \\
Tetralogy of Fallot & 12 \\
Atrial septal defects & 9 \\
Ventricular septal defects & 8 \\
Aortic stenosis & 5 \\
Coarctation of aorta & 1 \\
Pulmonary stenosis & 1 \\
Aortic aneurysm & 1 \\
\hline
\end{tabular}

Only occasionally was it necessary to use concentrations of methoxyflurane in excess of 05 per cent

During maintenance andesthesia and before surgical manipulation of the heart or great vessels, the systolic blood pressure remained relatively stable in 34 patients In 10 patients there was a moderate fall and in 6 there was a severe fall These results are recorded in Table $\mathbb{I I}$ The decrease in systolic blood pressure is expressed as a percentage of its preoperative value, or the value

TABLE II

Decrease in Systolic Blood Pressure in 50 Children with Congenital Hcart Disease during Methoxyflurane Anaesthesia

Percentage fall in blood pressure

Number of patients

$\begin{array}{rrr}0-10 & 10-30 & >30 \\ 34 & 10 & 6\end{array}$

immediately before the introduction of melhoxyflurane, if this was lower (4 patients) No one factor can be held responsible for the occurrence of hypotension during anaesthesia in such a valiable group of patients It is apparent from Table III that a fall of blood pressure in any one of the 6 patients would not be surprising regardless of the anaesthetic agent used

No bradycardia or tachycardia that could be attributed to methoxyflurane was noted in any patient $\mathbb{P}_{110 r}$ to manipulation of the heart two patients developed

TABLE IIII

Data OF 6 Patients Who had $>30 \%$

Fall in Blood Piressure

\begin{tabular}{|c|c|}
\hline $\begin{array}{c}\text { Maximum } \\
\text { methoxyflurane } \\
\text { concentration }(\%)\end{array}$ & Relevant data \\
\hline 15 & $\begin{array}{l}\text { VS D shunt reversal by positive } \\
\text { pressure }\end{array}$ \\
\hline 05 & A S D secundum, induced \\
\hline 05 & $\begin{array}{l}\text { Leaking aneurysm of the aortic } \\
\text { arch }\end{array}$ \\
\hline $\begin{array}{ll}1 & 5 \\
0 & 3\end{array}$ & $\begin{array}{l}\text { PDA } 14 \text { lb wt digitalized } \\
\text { Tetralogy Single ventricle } \\
\text { Severe pulmonary stenosis } \\
\text { Severe hypho scoliosis }\end{array}$ \\
\hline 05 & Tetralogy \\
\hline
\end{tabular}


transient arrhythmias which consisted of an A-V dissociation and occasional supraventricular extrasystoles

On completion of anaesthesia 31 patients were awake while 19 were not awake (Table IV) The pharyngeal reflexes were present in all cases The patients were considered to have recovered when they responded correctly to a simple command or, in the case of younger children, when the eyes opened spontaneously

TABLE IV

Immediate Post-anaesthetic State

\begin{tabular}{lcc}
\hline & Awake & Not awake \\
\hline Number of patients & 31 & 19 \\
\hline
\end{tabular}

In this type of surgery the recovery time is influenced by a number of factors other than the effect of a single drug However, the percentage of the anaesthetıc time during which methoxyflurane was being administered was a distunct factor determining whether or not the patient was awake at the end of surgery (Table V) The prospects of early recovery could have been increased either by

TABLE V

Immediate Post-Anaesthetic State

\begin{tabular}{lcc}
\hline \hline & \multicolumn{2}{c}{ Number of patients } \\
\cline { 2 - 3 } & Awake & Not awake \\
\hline $\begin{array}{c}\text { Methoxyfurane on for }>39 \% \text { of } \\
\text { anaesthetic time } \\
\begin{array}{c}\text { Methoxyflurane on for }<39 \% \text { of } \\
\text { anaesthetic time }\end{array}\end{array}$ & 17 & 17 \\
\hline$\chi^{2}$ test $P<001$ & 14 & 2 \\
\hline
\end{tabular}

turning the methoxyflurane off at an earlier stage or by reducing the inhaled concentration This was found to be unsatisfactory because of the inadequate anaesthesia which often resulted Reference to Figure 1 will show that in only 9 patients was the methoxyflumane administered fol more than 50 per cent of the operation

It can be seen from $\mathbb{F}$ igure 2 that the mean concentration of methoxyflurane delivered to the patients was over 04 per cent in only 13 cases The mean concentration includes a relatively high concent ation (rarely over $05 \%$ ) administered to the patient initially When anaesthesia was stable, concentrations of $02-03$ per cent were used for maintenance

In general, any effort to further limit the amount of methoxyflurane administered imparred the quality of the anaesthesia Also, in cardiac surgery, a number of other factors may prolong the normally slow elmmination of methoxyflurane Examples include reduction in pulmonary blood flow, reduction in systemic blood flow, and hypothermia In the postoperative period, respiratory depression may be an additional cause of slow elimination The following case report lllustrates some of these points 


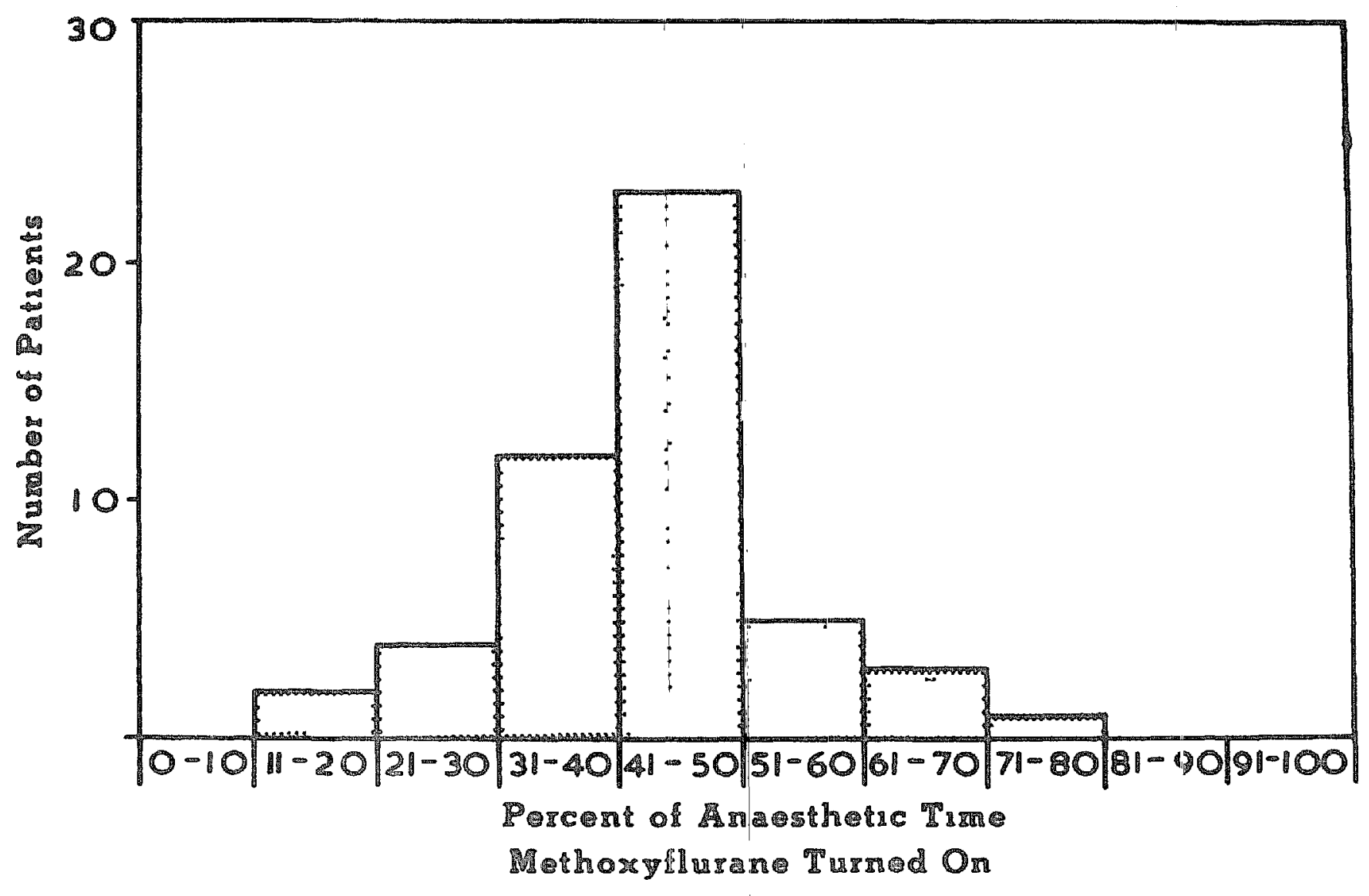

FICURE ]

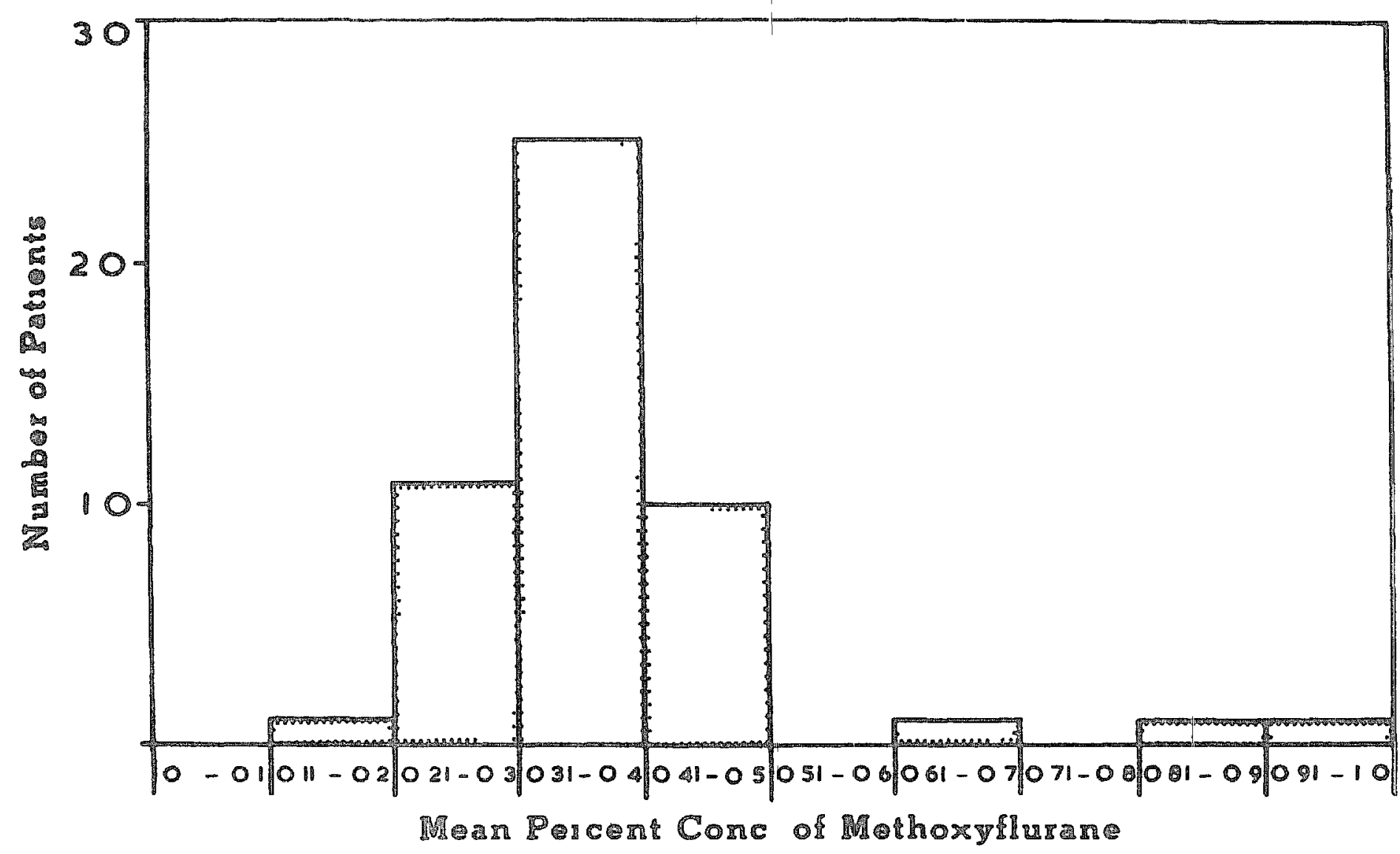

Figure 2

A Blalock anastomosis was performed under hypothermia on a child with cyanotic Tetralogy of Fallot, severe pulmonasy stenosis, severe kypho-scolosis, and a single ventricle A poorly functioning anastomosis was effected Duing a large part of the operation there was considerable hypotension On the cessation of anaesthesia, the pharyngeal reflexes were piesent but the patient was not awake The blood pressure was $50-60 \mathrm{~mm} \mathrm{Hg}$ systolic and there was a supraventricular tachycardia of $200 / \mathrm{mm}$ 
The patient was extubated It was noted that the odour of methoxyflurane in the patient's breath was unexpectedly strong The patient was, therefore, remtubated and artificially ventılated and awakened an hour later

It is not suggested that methoxyflurane was responsible for the prolonged recovery but only that it contributed to the patient's precarious postoperative condition Thrs occurred despite the fact that the drug was only administered for 15 per cent of the total anaesthetic time at a mean concentration of 023 per cent

Table VI records the postoperative analgesıc jequirements of 23 patients These patients are chosen because they received a high dose of methoxyflurane relative to the anaesthetic time (The dose was calculated on the assumption that $05 \%$ for $5 \mathrm{~mm} \equiv 01 \%$ for $5 \times 5 \mathrm{~mm}$ ) This selection serves to exclude the more ill patients, including all those who required $I \mathbb{P} \mathbb{P}$ in the postoperative period Persistent restlessness, interference with physiotherapy, and persistent irritability, all due to pain, were indications for giving pethedine 1-3 mg $1 \mathrm{~V} / 10 \mathrm{lb}$, or morphine $0 \mathrm{l}-03 \mathrm{mg} 1 \mathrm{v} / 10 \mathrm{lb}$ Doses 1 epeated within one-half hour were regarded as being single

TABLE VI

Post-operative tnalgesics Required by 23 Patients Who Received a Relatively High Dose of Methoxyflurane

\begin{tabular}{|c|c|c|c|c|}
\hline \multicolumn{3}{|c|}{$\begin{array}{l}\text { Doses of analgesic in } \\
\text { first } 12 \text { hours } \\
\text { postop }\end{array}$} & \multicolumn{2}{|c|}{$\begin{array}{l}\text { Time from end of operation } \\
\text { until first dose of } \\
\text { andlgesic (min) }\end{array}$} \\
\hline & $\begin{array}{l}\text { tients } \\
\text { ke }(8)\end{array}$ & $\begin{array}{c}\text { Patients } \\
\text { not awdke (15) }\end{array}$ & $\begin{array}{r}\text { Patients } \\
\text { awake (8) }\end{array}$ & $\begin{array}{c}\text { Patients } \\
\text { not awake (15) }\end{array}$ \\
\hline & $\begin{array}{l}4 \\
6 \\
4 \\
4 \\
5 \\
4 \\
3 \\
5\end{array}$ & $\begin{array}{l}5 \\
4 \\
5 \\
4 \\
1 \\
4 \\
5 \\
5 \\
5 \\
4 \\
5 \\
0 \\
6 \\
2 \\
2\end{array}$ & $\begin{array}{r}25 \\
10 \\
15 \\
5 \\
15 \\
5 \\
25 \\
5\end{array}$ & $\begin{array}{c}20 \\
300^{*} \\
5 \\
5 \\
75^{*} \\
300 \\
55 \\
25 \\
10 \\
165^{*} \\
50 \\
90 \\
25 \\
350^{*} \\
35\end{array}$ \\
\hline Mean & 44 & 381 & 131 & $656 \ddagger$ \\
\hline
\end{tabular}

Durng the first 12 postoperative hours there was no significant difference in the number of doses of analgesic required by the patients who were awake and those who were not awake at the cessation of anaesthesia This occurred despite the fact that the first dose was not given for an average of 65 minutes after the completion of surgery in the latter group The patients who were awake required 
an analgesic an average of 13 minutes after the completion of surgery Methoxyflurane could easily be detected in the exhalations of all these patients These results suggest, firstly, that following chest surgery in children, methoxyllurane exerts little or no analgesic action once the patients are awake, and secondly, that the analgesia it does give is at the expense of a reduced level of consciousness The 4 patients in Table VI marked with an asterisk could only be roused after consıderable stımulation in the early postoperative period, and did not awaken for periods of 60 minutes, 45 minutes, 120 minutes, and 50 minutes, respectively

\section{Discusston}

It is well known that methoxyflurane calises cardiovascular depression, but in a healthy patient a significant fall of blood pressure is not likely to occur if overdosage is avouded ${ }^{3}$ There may be a considerable fall of blood pressure, however, if the patient's compensatory mechanisms are madequate This is apparent from our results and those of other clinical studies 501011,12

Methoxyflurane has little tendency to induce spontaneous cardiac arrhythmias ${ }^{31314}$ There is evidence that it sensitizes the heart to the action of adrenaline ${ }^{1516}$ This drug is not infrequently used in cardiac surgery as a circulatory stimulant Any disadvantages that methoxyflurane may have in this respect in cardiac surgery are difficult to evaluate and are not within the scope of this study

The drawback of the slow rate of uptake of methoxyflurane can largely be offset by the use of an intravenous induction Although recovery times in the many published reports on the clinical use of methoxyflurane have varied considerably, all authors are agreed that prolonged recovery is a special feature of anaesthesia with this agent ${ }^{5} 6101112$ This constitutes a distinct disadvantage to its use in cardiac surgery with the described technique Efforts to have the patient awake at the end of surgery by reducing the inhaled concentration or by earlier withdrawal of methoxyflurane can easily result in unsatisfactory anaesthesia during the procedure Should this orcur, it is difficult to remedy owing to the inflexible nature of the agent Factors which adversely affect elimination are not infrequently present and further add to the difficulty of having the patient awake immediately postoperatively

It is highly debatable whether methoxyflurane possesses a specific analgesic action of any significance Torda ${ }^{17}$ concludes from analgesimetry studies that it "appears" to have His results, however, are not very consistent Dundee and Love, ${ }^{18}$ also using analgesimetry, state that methoxyflurane in subnarcotic doses has no significant analgesic action The results of this study support ther view Many authors of reports regarding the clunical use of methoxyflurane are of the opinion that it exhibits a prolonged analgesia in the postoperative period ${ }^{4-9} \mathrm{Few}$ of the patients involved were awake at the end of surgery There was a gradual emergence until at varying periods of time after the operation the patients were able to obey simple commands Following this, many of the patients remained drowsy or somnolent, but pan-free and edsily aroused There is no objection to somnolence in a co-operative patient after cardiac surgery, and this is a side- 
effect of many analgesic drugs The analgesia provided by the opiate drugs, however, is superior to that offered by methoxyflurane to the extent that it is controllable, dependable, can be adjusted to the requirements of the patient, and is easily achieved Using methoxyflurane with the above technique in paediatric cardiac surgery, to consistently provide an awake patient, who is also in such a state of emergence as to be analgesic and co-operative, is practically impossible It is sufficiently difficult even to have the patient awake at the end of surgery

\section{Conclusions}

From our results in children, it is doubtful that methoxyflurane possesses a spectic analgesic action Because of its slow elmmination and associated prolonged recovery, this agent is contrandicated in paediatric cardiac surgery, using the technique described

\section{SUMMARY}

Methoxyflurane in mitrous oxide and oxygen was administered to 50 children who underwent surgery for the correction of congental heart defects The patients were hyperventilated using a semi-closed system and Waters canıster, incorporating a Pentec vaporizer outside the curcuit The results suggest that following anaesthesia with methoxyflurane in children, there is little analgesia in the awake patient Because of the prolonged recovery associated with methoxyflurane anaesthesia, this agent is regarded as being unsuitable for use in paediatric cardıac surgery

\section{ACKNOWLEDGMENTS}

We gratefully acknowledge the assistance given by our anaesthetic colleagues, the surgical residents, and Dr W $T$ Mustard and Dr G T Trusler, under whose care the patients were admitted

\section{RÉSUMÉ}

Nous avons administré du méthoxyflurane avec du protoxyde d'azote et de l'oxygène à 50 enfants qui devalent être opérés pour corriger une anomalıe congénitale du coeur Nous avons hyperventilé ces malades en employant un circuit semi-fermé et l'absorbeur de Waters, et nous avons uttlisé le vaporisateur Pentec en clehors du circuit Les résultats, nous portent à croire que, à la suite de l'anesthésie au méthoxyflurane chez les enfants, il persiste un légère analgésie chez le malade révelllé A cause du révell tardif à la surte de l'anesthésie au méthoxyflurane, nous considérons que cet agent n'est pas appropré pour la chiru gie cardiaque chez les enfants

\section{REFERENCES}

1 Smith, C Personal communication (1983)

2 Domin, A B \& FEDORUK, $S$ Comparison of the Cardiovascular, Respiratory and 
Metabolic Effects of Methoxyflurane and Halothane in Dogs Anesthesiology 22355 (1961)

3 Artusio, J F, van Poznak, A, Hunt, R E, Tiens, F M, \& Alexander, M A Clinical Evaluation of Methoxyflurane in Man Anesthesiology 21512 (1960)

4 Romagnoli, A \& Korman, D Methoxyflurane in Obstetrical Anaesthesia and Analgesia Canad Anaesth Soc J 9414 (1962)

5 Denton, M V H \& Tonda, T A G Methoxyflurane Clinical Experiences in 50 Orthopaedic Cases Anaesthesia 18279 (1963)

6 Jarman, $R$ \& Edghill, H B Methoxyflurane (Penthrane) A Clinical Investigation Anaesthesia 18265 (1963)

7 Power, D T McGill University Experiences with Methoxyflurane Canad Anaesth Soc J 8488 (1961)

8 McIntyre, J W R \& Gain, E A Methoxyflurane Canad Anaesth Soc J 9319 (1962)

9 Thomason, R, Light, G, \& Holaday, D A. Methoxyflurane Anaesthesia A Clinıcal Appraisal Anaesth \& Analg 41225 (1962)

10 Hudon, F Methoxyflurane Canad Anaesth Sod J 8544 (1961)

11 Wyant, G M, Chang, C A, \& Rapicavoli, E Methoxyflurane (Penthrane) A Laboratory and Clinical Study Canad Anaesth Soc J 8477 (1961)

12 van Poznak, A Clinical Administration of Methoxythurane Clinical Anaesthesia, vol 1, Halogenated Anaesthetıcs Edited by J F Artusı Philadelphia F A Davis Co (1963)

13 Wasmuth, C E, Greig, J H, Homi, J, Moraca, P P, Isil, N H, Bitte, E M, \& Hale, D E Methoxyflurane-New Anaesthetic Agent Cleveland Clin Quart 27 174 (1960)

14 BAgwell, E E \& Woods, E F Cardiovascular Effects of Methoxyflurane Anesthesiology 22169 (1962)

15 Bamforth, F J, Siebecker, K L, Kraemer, R, \& Orth, O S Effect of Epinephrine on the Dog Heart during Methoxyflurane Anaesthesia Anesthesiology 22; 169 (1961)

16 Nonth, W C \& KNox, P R Influence of Methoxyflurane upon Cardiovascular Response to Epinephrine Fed Proc 20312 (1961)

17 Tonda, T A The Analgesic Effect of Methoxyflurane Andesthesia 18287 (1963)

18 Dundee, J W \& Love, W J Alterations in Response to Somatic Pain Associated with Anaesthesia XIV Effects of Subnarcotic Concentrations of Methoxyflurane Brit J Anaesth 35301 (1963) 